\title{
Population structure of Rudgea parquioides (Rubiaceae), a shade-tolerant shrub species, in Southern Brazil
}

\author{
FERNANDA C.G. CARDoso, ANA P.B. SALVALAGgio and MÁRCia C.M. MARQUES \\ Laboratório de Ecologia Vegetal, Departamento de Botânica, Setor de Ciências Biológicas \\ Universidade Federal do Paraná, Caixa Postal 19031, 81531-980 Curitiba, PR, Brasil
}

Manuscript received on April 28, 2009; accepted for publication on April 12, 2010

\begin{abstract}
The expectations that shade-tolerant forest species show 1) a population structure composed by a high amount of small individuals, and 2) biomass allocation for diameter higher than for height growth, were tested for Rudgea parquioides, a typical shrub in Southern Brazil. We described the size structure (height and stem diameter) and allometrical relations of a $R$. parquioides population by counting and measuring all the individuals in a $725 \mathrm{~m}^{2}$ area in the municipality of Curitiba $\left(25^{\circ} 25^{\prime} \mathrm{S} ; 49^{\circ} 19^{\prime} \mathrm{W}\right)$. A total of 916 individuals $\left(12,634\right.$ ind.ha $\left.^{-1}\right)$ were recorded in the area. The first expectation was supported, since distribution by height and diameter classes showed a predominance of small individuals (skewness coefficients $>1$ ). On the other hand, the regression between height and stem base diameter showed slope $\beta<1$, which indicates that growth in height is higher than in diameter, not supporting the second expectation. These results show that life strategies in shade-tolerant species may imply in more trade-off combinations than previously described.
\end{abstract}

Key words: allometry, Araucaria forest, size distribution, subtropical forest, understorey.

\section{INTRODUCTION}

Plant populations can be described in terms of age, size and shape of its individuals and genetic structure (Harper and White 1974). Differences in size can be caused by factors such as age, genetic variability, resources heterogeneity, competition, effect of herbivore, parasites or pathogens and disturbance (Weiner and Solbrig 1984, Coomes et al. 2003, Muller-Landau et al. 2006). If size structure is related to the age of individuals, it gives information on the current regenerating capacity, past disturbances (Knowles and Grant 1983, Agren and Zackrisson 1990) and future expected occurrences (Odum 2001).

Light quantity and quality are strong factors determining plant growth and population structure in plant communities (Franklin 2003, Falster and Westoby 2005,

Correspondence to: Fernanda C. Gil Cardoso

E-mail: fercardoso@hotmail.com
Poorter et al. 2006). Irradiance can fluctuate from 1-2\% of light at the forest floor to $100 \%$ above the canopy (Poorter et al. 2006). To take most advantage of the light available, species partition access to light through tradeoffs between growth-rate, stem-persistence and shadetolerance (Wright 2002, Falster and Westoby 2005).

For tropical plant communities, it is suggested that gap-depending tree species are usually characterized by size distributions with many large individuals and a long tail of relatively rare, small individuals with large fecundity, seed and seedling mortalities (Wright et al. 2003). On the other hand, size distributions with many small individuals and a long tail of relatively rare, large individuals characterized shade-tolerant species with the opposite traits (Poorter et al. 1996, Kohira and Ninomiya 2003, Wright et al. 2003). Thus, population size structure is an important tool to understand plant strategies to survival according to the light availability. 
The dimensional relationships (allometry) in plants have been used as an indicator of growth strategy of trees (Niklas 1994, Bohlman and O'Brien 2006). Tree architecture is a strong determinant of mechanical safety (van Gelder et al. 2006). As shade-tolerant species, understorey trees have morphologies that increase light interception and persistence by allocating more biomass for diameter growth than height. In contrast, saplings from canopy trees allocate their biomass for efficient height growth and pass through the understorey to reach the high-light environment of the canopy (King 1990, van Gelder et al. 2006). Even though this relationship is well known for trees (King 1990), no information is available for understorey shrubs. It is supposed that, as a shade-tolerant species, shrubs increase light interception and persistence by allocating more biomass for stem (or stems) radial growth.

Rudgea parquioides (Cham.) Muell. Arg. (Rubiaceae) is an endemic shrub of Araucaria forest, occurring in South and Southeast Brazil, as well as in portions of Paraguay and Argentina (Smith and Downs 1956). Its habitat comprises the understorey of the densest regions of Araucaria forest and, in Southern Brazil, is frequently one of the most important species in terms of abundance (Kozera et al. 2006). Here, we studied the population of $R$. parquioides, a shade-tolerant species, in Southern Brazil. Specifically, we addressed the following questions: 1) if this population shows a juveniledominated size structure; 2) if the relationship between diameter and height indicates higher biomass allocation for diameter.

\section{MATERIALS AND METHODS}

This study took place in a 50-ha Araucaria forest remnant in Curitiba, Eastern Paraná State, Brazil $\left(25^{\circ} 25^{\prime} \mathrm{S}\right.$, $49^{\circ} 19^{\prime} \mathrm{W}, 900 \mathrm{~m}$ a.s.1.). The Araucaria forest is distributed in Southern Brazil, Eastern Paraguay and Northern Argentina. This rain forest is dominated by the endemic species Araucaria angustifolia (Bertol.) Kuntze, and lies in a transition zone between tropical and temperate climates, with rainfall throughout the whole year and moderate temperatures (Hueck 1953). Since monthly minimum rainfall exceeds $60 \mathrm{~mm}$, this forest may be considered as weakly seasonal with respect to rainfall (Wright and Van Schaik 1994). Araucaria forests oc- cupy only a small fraction of their former range and are rapidly disappearing, with some contiguous remaining forests currently found in the state of Paraná, Southern Brazil (e.g. 1.3\% in Paraná, Britez and Castella 2004). These forests show particular features by virtue of its ecotonal location (Marques et al. 2004), but little is known about its local species dynamics (Oliveira and Pillar 2004).

The climate in the region is Cfb in Köppen's classification system, i.e. humid subtropical and mesothermic with mild winters and occasional hard frosts and no pronounced dry season (Iapar 1978). The average monthly temperature ranges from $13^{\circ} \mathrm{C}$ (in June to July) to $21^{\circ} \mathrm{C}$ (in February). Annual precipitation during the 1970-95 period averaged $1389 \mathrm{~mm}$, with greatest rainfall in January and February and least in July and August (Marques et al. 2004).

The studied fragment is characterized by having three distinct strata, with Lauraceae species in the superior layer and many Rubiaceae and Myrtaceae species in the intermediate and inferior layers. The only emergent species occurring is Araucaria angustifolia which, with its unique crown architecture (candelabriform), gives a peculiar physiognomic aspect to this kind of forest (Dittrich et al. 1999, Kozera et al. 2006).

The study was conducted in a $725 \mathrm{~m}^{2}$ plot, subdivided in $29(5 \times 5 \mathrm{~m})$ non-contiguous sub-plots (two blocks apart $200 \mathrm{~m}$ from each other). All individuals of Rudgea parquioides were marked and had their height and stem base diameter measured. As all juveniles and adults (height $>32.2 \mathrm{~cm}$ ) were branched at a minimum of five centimeters above soil level, only one measure of stem diameter was necessary for each individual.

The data were compiled and analyses were performed to assess the pattern of size structure and growth of the individuals in the population. To evaluate the frequency distribution for height and diameter, we first tested for normality and log-normality of data using Shapiro-Wilk and Kolmogorov-Smirnov-Lilliefors (KSL) tests, respectively (Zar 1999). After that, we chose among coefficient of variation, Gini coefficient or skewness coefficient for verifying the size distribution within the population (Bendel et al. 1989). The skewness coefficient was chosen because the size distribution was approximately log-normal. It indicates whether 
the size distribution has long tails to the left $\left(g_{1}<0\right)$, or to the right $\left(g_{1}>0\right)$, or whether the distribution is symmetrically bell-shaped $\left(g_{1}=0\right)$. We presented size distribution in size classes (following Vandermeer 1978) because they are more comparable to the other population studies.

To examine the growth pattern, we verified the relationship between height and diameter by performing a standardized major axis (SMA). This analysis is indicated for allometrical relationships in plants and transform $(\log )$ the equation $\mathrm{y}=\gamma \cdot \mathrm{x} \beta$ to a linear regression (Warton et al. 2006). The 1:1 slope $(\beta=1)$ in the height $(\mathrm{x})$ by diameter $(\mathrm{y})$ regression indicates the symmetrical growth in height and diameter; $\beta>1$ indicates a higher growth in diameter than in height, and $\beta<1$ shows a higher growth in height than in diameter. We also performed SMA for juveniles and adults separately to assess possible differences in growth pattern among the stages.

\section{RESULTS}

A total of 916 Rudgea parquioides individuals was recorded, representing an estimated density of 12,634 ind.ha ${ }^{-1}$. The median height of the population was $44.5 \mathrm{~cm}$ (maximum $=370 \mathrm{~cm}$; minimal $=1.42 \mathrm{~cm})$, and the median diameter was $0.54 \mathrm{~cm}$ (maximum $=4.56 \mathrm{~cm}$; minimal $=0.06 \mathrm{~cm}$ ).

Height and diameter were not normally distributed $(\mathrm{W}=0.84$ and 0.85 , respectively, $\mathrm{P}<0.001)$ but approximately log-normally distributed $(\mathrm{D}=0.09, \mathrm{P}<$ $0.01)$. The skewness coefficient $\left(g_{1}\right)$ for height and diameter were, respectively, $g_{1}=1.12$ and $g_{1}=1.37$, confirming the distribution with a long tail to the right (all $g_{1}>0$ ). The distribution by height and diameter classes (Figs. 1a and 1b) showed a predominance of individuals in the first classes $(1.42-32.2 \mathrm{~cm}$ in height and $0.06-0.38 \mathrm{~cm}$ in diameter).

Plant height and stem base diameter were highly related $\left(r^{2}=0.76 ; \mathrm{P}<0.0001\right.$; Fig. 2$)$, which is expected for all allometrical relationships. Nevertheless, the slope $( \pm \mathrm{CI})$ was lower than $1(0.74 \pm 0.02)$, which indicates a superior growth in height rather than in diameter. Even when juveniles (height $=1.42-32.2 \mathrm{~cm}$ ) and adults (height $>32.2 \mathrm{~cm}$ ) were analyzed separately, this tendency was confirmed (juveniles: $r^{2}=0.15$; $\mathrm{P}<0.0001$; slope $=0.92 \pm 0.08$; adults: $r^{2}=0.63$; $\mathrm{P}<0.0001 ;$ slope $=0.97 \pm 0.05)$.

\section{DISCUSSION}

The expectations that shade-tolerant species show a juvenile-dominated size structure and allocate more biomass for diameter than for height were partially supported for the studied population of Rudgea parquioides. These results show that the growth strategies vary among shade-tolerant shrubs and trees, as pointed out for several tropical and sub-tropical species (Wright et al. 2003, Souza 2007).

The $R$. parquioides population showed a positive skewness coefficient for height and diameter, which represents a long tail of individuals in the right side of the curve. Since larger individuals are distributed in this long tail, the population also fitted a "J-reverse" curve distribution in size classes (Leak 1965). Both situations indicate a strong hierarchy among individuals (Weiner and Solbrig 1984), where a small number of large individuals impose a stronger competitive pressure over small individuals. This behavior has been associated to shade-tolerant tree species, which have size distributions with many small individuals and a long tail of relatively rare, large individuals, the larger ones contributing in a more significant way to the population total biomass (Poorter et al. 1996, Kohira and Ninomiya 2003, Wright et al. 2003). The juvenile dominated size structure of $R$. parquioides indicates that understorey shrubs also grow slowly, which results in the seedling permanence in the forest floor for long periods.

The high density of seedlings and juvenile individuals reflects the occurrence of constant and intense reproductive events (Ramirez and Arroyo 1990) or seedling bank (Harper and White 1974). In fact, the population produced fruits during the two preceding years of the demographic study (Marques et al. 2004). The seeds are animal-dispersed between December and May, period with the best temperature and humidity conditions for germination (Marques et al. 2004). Factors related to high density effects, such as herbivore and pathogens attacks (Janzen 1970, Augspurger 1983, Clark and Clark 1987) and also interactions with other species from the 

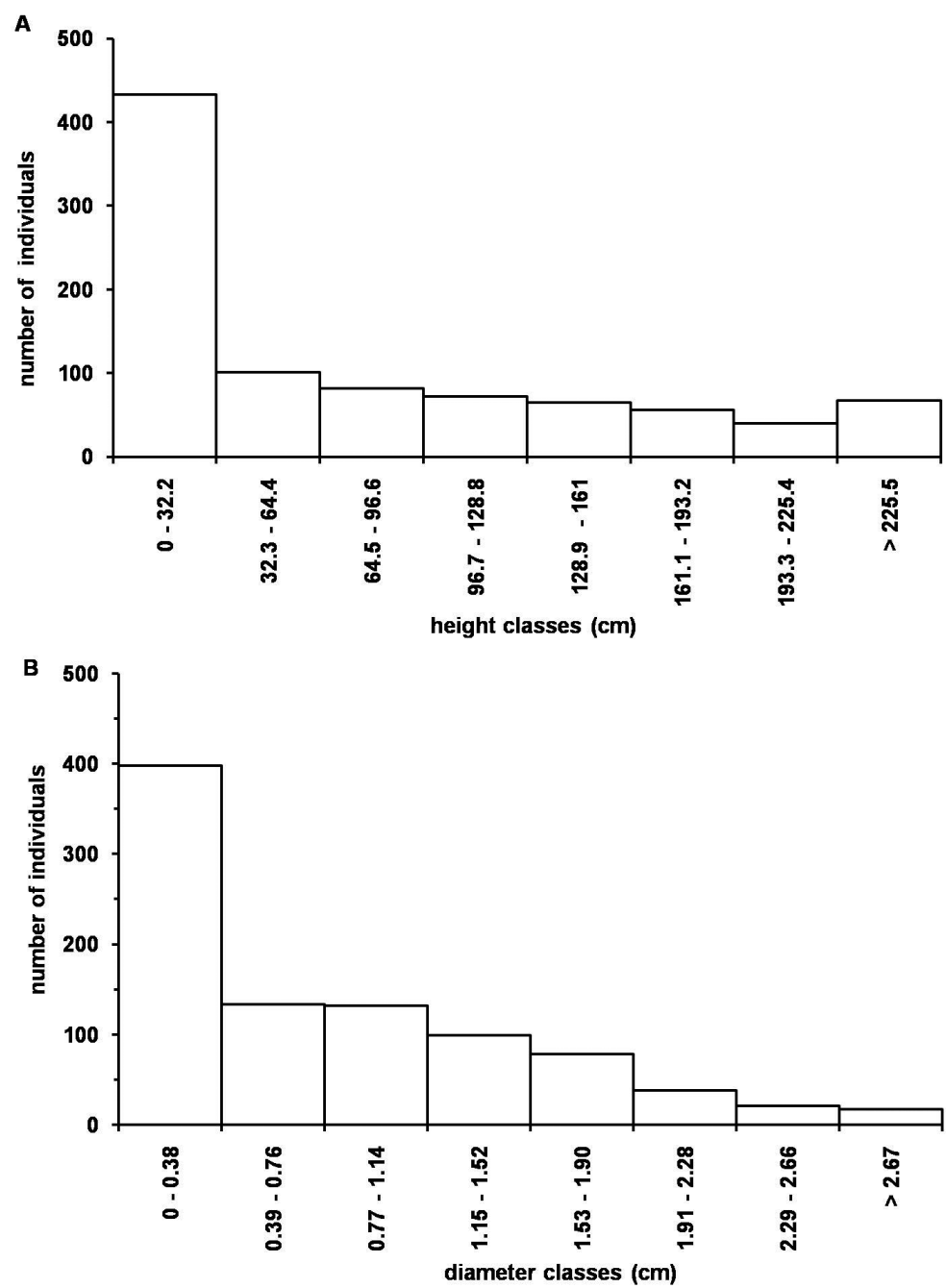

Fig. 1 - Number of individuals in height (a) and diameter (b) classes of a Rudgea parquioides (Rubiaceae) population in an Araucaria forest fragment in Curitiba, Southern Brazil.

community, could cause mortality of small individuals, reducing the density of larger individuals in the studied population.

$R$. parquioides plants showed an allometric growth, demonstrated by the strong relationship between height and diameter. Tropical species often show significant regressions between height and diameter (Alvarez-Buylla and Martinez-Ramos 1992, Santos 2000). This trend seems to be genetically determined (Santos 2000) and related to an equal resource distribution for growth in width and height (Niklas 1994). It was expected that, as an understorey species, $R$. parquioides had a tendency of allocating more biomass for diameter growth than for height, since it needs to have morphologies that increase light interception and persistence (King 1990). Nevertheless, the studied population (all stages) tended to allocate higher biomass to height than to diameter (slope $<1$ ), although juveniles and adults showed a marginally 1:1 allometric relationship. The higher diameter allocation is believed to improve stem persistence (Wright et al. 2003, Falster and Westoby 2005). This result suggests that, despite shade-tolerant tree species allocate more biomass to stem growth to sustain the weight of the branches and leaves (Poorter et al. 2006), in shadetolerant shrub species, the stem biomass can be inferior because the branches are not so weighty. These findings suggest that allometric plant strategies are more complex than previously thought. 


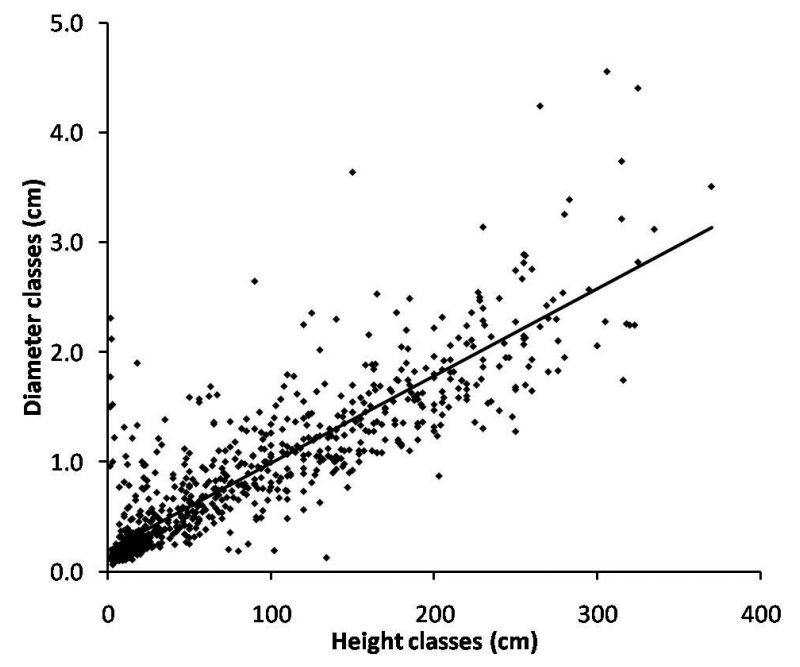

Fig. 2 - Relationship between stem diameter and height of the Rudgea parquioides (Rubiaceae) population in an Araucaria forest fragment in Curitiba, Southern Brazil.

Whereas light is a limiting resource for plants, the growth and survival in the intensely shaded understorey demand a complex strategy to optimize light uptake and, thus, allow persistence and reproduction (Wright et al. 2003). Even if persistence (measured by higher diameter growth) is unimportant, the population structure dominated by small individuals suggests a considerable autoregenerating potential for $R$. parquioides. Then, regarding growth and size structures, life strategies for shadetolerant species may imply in more trade-off combinations than previously described.

\section{ACKNOWLEDGMENTS}

Thanks to the Prefecture of the Municipality of Curitiba for permission to carry out this research in Barigüi Park. Thanks to F.H. Mello Leitão for helping in the data organization. A.P.B. Salvallaggio received support from the program Iniciação Científica at Universidade Federal do Paraná.

\section{RESUMO}

Foram testadas duas hipóteses relativas a espécies florestais tolerantes à sombra em uma população de Rudgea parquioides, um arbusto característico do sul do Brasil: 1) espécies tolerantes à sombra possuem uma estrutura populacional composta por um grande número de indivíduos pequenos e 2) a alocação de biomassa para o crescimento em diâmetro é maior que para o crescimento em altura. Foram descritas as estruturas de tamanho (altura e diâmetro do tronco) e relações alométricas através da contagem e medição de todos os indivíduos de $R$. parquioides em uma área de $725 \mathrm{~m}^{2}$ no município de Curitiba $\left(25^{\circ} 25^{\prime} \mathrm{S} ; 49^{\circ} 19^{\prime} \mathrm{W}\right)$. Um total de 916 indivíduos (12.634 ind.ha $\left.{ }^{-1}\right)$ foi medido nesta área. A primeira hipótese foi aceita, uma vez que a distribuição em classes de altura e de diâmetro mostrou um predomínio de indivíduos pequenos (coeficiente de assimetria >1). Por outro lado, a regressão entre altura e diâmetro na base do caule mostrou inclinação $\beta<1$, o que indica que o crescimento em altura é maior que em diâmetro, não suportando a segunda hipótese. Esses resultados mostram que as estratégias de crescimento em espécies tolerantes à sombra podem implicar em outras relações ecológicas além das já descritas.

Palavras-chave: alometria, floresta com Araucária, distribuição de tamanho, floresta subtropical, sub-bosque.

\section{REFERENCES}

Agren J AND ZaCKRisson O. 1990. Age and size structure of Pinus sylvestris populations on mines in central and northern Sweden. J Ecol 78: 1049-1062.

Alvarez-Buylla ER AND Martinez-RAmos M. 1992. Demography and allometry of Cecropia obtusifolia, a neotropical pioneer tree - an evaluation of the climax-pioneer paradigm for tropical forests. J Ecol 80: 275-290.

Augspurger CK. 1983. Seed dispersal of tropical tree Platipodium elegans, and the escape of its seedlings from fungal pathogens. J Ecol 71: 759-771.

Bendel RB, Higgins SS, Teberg Je and Pyke DA. 1989. Comparison of skewness coefficient, coefficient of variation, and Gini coefficient as inequality measures within populations. Oecologia 78: 394-400.

Bohlman SA AND OBRIEN ST. 2006. Allometry, adult stature and regeneration requirements of 65 tree species on Barro Colorado Island, Panama. J Trop Ecol 22: 123136.

Britez RM AND CASTElla PR. 2004. A Floresta com Araucária no Paraná: conservação e diagnóstico dos remanescentes florestais. Brasília: Ministério do Meio Ambiente, $233 \mathrm{p}$.

Clark DB AND Clark DA. 1987. Population ecology and microhabitat distribution of Dypterix panamensis, a neotropical rain forest emergent tree. Biotropica 19: 236244.

Coomes DA, Duncan RP, Allen RB And TruscotT J. 2003. Disturbances prevent stem size-density distri- 
butions in natural forests from following scaling relationships. Ecol Lett 6: 980-989.

DitTrich VAO, Kozera C And Silva SM. 1999. Composição florística de epífitos vasculares em área de Floresta Ombrófila Mista (Parque Barigüi), Curitiba, PR. Iheringia Ser Bot 52: 11-22.

FAlster DS AND WeStoby M. 2005. Alternative height strategies among 45 dicot rainforest species from tropical Queensland, Australia. J Ecol 93: 521-535.

FRANKLIN J. 2003. Regeneration and growth of pioneer and shade-tolerant rain forest trees in Tonga. New Zeal J Bot 41: 669-684.

HARPER JL AND White J. 1974. The demography of plants. Annu Rev Ecol Sys 5: 419-463.

HUECK K. 1953. Distribuição e habitat natural do Pinheirodo-Paraná (Araucaria angustifolia). Bol Fac Fil Ci Let USP- Botânica 10: 1-24.

IAPAR. 1978. Cartas climáticas básicas do estado do Paraná. Fundação Instituto Agronômico do Paraná, Londrina.

JANZEN DH. 1970. Herbivores and the number of tree species in tropical forest. Am Nat 940: 501-528.

KING DA. 1990. Allometry of saplings and understorey trees of a Panamanian Forest. Funct Ecol 4: 27-32.

KNOWLES P AND GRANT M. 1983. Age and size structure analyses of engelmann spruce, ponderosa pine, lodgepole pine, and limber pine in Colorado. Ecology 64: 1-9.

Kohira M And NinomiYA I. 2003. Detecting tree populations at risk for forest conservation management: using single-year vs. long-term inventory data. Forest Ecol Manag 174: 423-435.

Kozera C, DitTrich VAO And Silva SM. 2006. Fitossociologia do componente arbóreo de um fragmento de Floresta Ombrófila Mista Montana, Curitiba, PR, Brasil. Rev Floresta 36: 225-237.

LEAK WB. 1965. The J-shaped probability distribution. Forest Sci 11: 405-19.

Marques MCM, Roper JJ And Salvalaggio APB. 2004. Phenological patterns among plant life forms in a Subtropical Forest in Southern Brazil. Plant Ecol 173: 191-201.

Muller-Landau HC ET AL. 2006. Comparing tropical forest tree size distributions with the predictions of metabolic ecology and equilibrium models. Ecol Lett 9: 589-602.

NiKLAS KJ. 1994. Plant allometry: the scaling of form and process. Chicago: The University of Chicago Press, $395 \mathrm{p}$.
ODUM E. 2001. Fundamentos de Ecologia. Lisboa: Fundação Calouste Gulbenkian, 434 p.

OLIVEIRA JM AND PILLAR VD. 2004. Vegetation dynamics on mosaics of Campos and Araucaria forest between 1974 and 1999 in Southern Brazil. Community Ecol 5: 197202.

POORTER L, BONGERs F, VAN ROMPAEY RSAR AND KLERK M. 1996. Regeneration of canopy tree species at five sites in West African moist forest. Forest Ecol Manag 84: 61-69.

Poorter L, Bongers L And Bongers F. 2006. Architecture of 54 moist-forest tree species: traits, trade-offs and functional groups. Ecology 87: 1289-1301.

RAMIREZ N AND ARROYO MK. 1990. Estructura poblacional de Copaifera publifora Benth. (Leguminosae; Caesalpinioideae) en los altos llanos centrales de Venezuela. Biotropica 22: 124-132.

SANTOS FAM. 2000. Growth and leaf demography of two Cecropia species. Rev Bras Bot 23: 133-141.

SMith LB AND Downs RJ. 1956. Resumo preliminar das Rubiáceas de Santa Catarina. Sellowia 7: 13-86.

SoUZA AF. 2007. Ecological interpretation of multiple population size structures in trees: The case of Araucaria angustifolia in South America. Austral Ecol 32: 524-533.

van Gelder HA, Poorter L AND Sterck FJ. 2006. Wood mechanics, allometry, and life-history variation in a tropical rain forest tree community. New Phytologist 171: 367-378.

VANDERMEeR J. 1978. Choosing categories size in a stage projection matrix. Oecologia 32: 79-84.

WArton DI, Wright IJ, Falster DS And Westoby M. 2006. Bivariate line-fitting methods for allometry. Biol Rev 81: 259-291.

Weiner J AND Solbrig OT. 1984. The meaning and measurement of size hierarchies in plant populations. Oecologia 61: 334-336.

WRIGHT SJ. 2002. Plant diversity in tropical forests: a review of mechanisms of species coexistence. Oecologia 130: 114.

Wright SJ AND VAN SCHAIK CP. 1994. Light and the phenology of tropical trees. Am Nat 143: 193-199.

Wright SJ, Muller-Landau H, Condit R and HubBELL SP. 2003. Gap-dependent recruitment, realized vital rates, and size distributions of tropical trees. Ecology 84: 3174-3185.

ZAR JH. 1999. Biostatistical analysis. New Jersey: PrenticeHall, 663 p. 